\title{
A Monoclonal Antibody to Rhesus Erythrocyte Band 3 Inhibits Invasion by Malaria (Plasmodium knowlesi) Merozoites
}

\author{
louis H. Miller, Diana Hudson, Joan Rener, Diane Taylor, \\ Terence J. Hadley, and Dan Zilberstein, Laboratory of Parasitic Diseases \\ and Laboratory of Microbial Immunity, National Institute of Allergy and \\ Infectious Diseases, National Institutes of Health, Bethesda, Maryland 20205
}

A B S T R A C T Receptors on erythrocytes and malaria parasites mediate specific attachment and junction formation between these cells that lead to invasion of the erythrocytes. We identified a monoclonal antibody A9 and its subclone A9D3 that bound to rhesus erythrocytes and blocked invasion of the erythrocytes by Plasmodium knowlesi merozoites. The monoclonal antibodies did not block attachment, the initial step in invasion, although swelling and crenation of the erythrocyte, which normally occur after attachment, were rarely observed in the presence of antibody. The monoclonal antibody immunoprecipitated rhesus erythrocyte band 3 . It bound to erythrocytes of another Old World monkey, the kra monkey, but not to erythrocytes of New World monkeys, chimpanzees, or man. Since the antibody did not bind to human erythrocytes, we could test for nonspecific toxicity to the parasite by studying the effect of the ascites and purified antibody on invasion of human erythrocytes. The antibody caused a minimal reduction in invasion of human erythrocytes, a reduction no greater than that seen with an unrelated monoclonal antibody. Further evidence that the inhibition was specific came from study of Fab fragments of A9D3. Column-purified Fab fragments reduced invasion of rhesus erythrocytes without affecting invasion of human erythrocytes. Fab fragments preabsorbed with rhesus erythrocytes did not inhibit invasion. From the above data, we conclude that band 3 is involved in a stage in the invasion process after initial recognition.

Dr. Rener's present address is Hazelton Laboratories America, Vienna, VA 22180.

Received for publication 2 December 1982 and in revised form 22 June 1983.

\section{INTRODUCTION}

Malaria merozoites invade erythrocytes by a sequence of steps that begin with specific attachment between any part of the merozoite and the erythrocyte (1). The merozoite reorients so that its apical end will be in apposition to the erythrocyte. A junction then forms between the apical end of the merozoite and the erythrocyte $(2)$.

Since each species of malaria will only recognize erythrocytes from a limited range of host species, there must be specific receptors for recognition (3-5). Erythrocyte receptors for invasion have been partially characterized for Plasmodium knowlesi, a monkey malaria that also invades human erythrocytes $(4,5)$. Duffy blood group negative human erythrocytes are refractory to invasion by $P$. knowlesi (6). The initial attachment and apical reorientation, however, appear normal with Duffy-negative erythrocytes, but the parasite is unable to form a junction with these erythrocytes (7). Therefore the initial recognition between merozoite and erythrocyte is probably unrelated to the Duffy blood group system.

We now show that a monoclonal antibody to rhesus erythrocyte band 3 and Fab fragments of the antibody inhibit invasion of rhesus erythrocytes by $P$. knowlesi merozoites. The antibodies, however, do not block initial attachment, an observation analogous to studies on Duffy-negative human erythrocytes. This suggests that both band 3, the major transmembrane protein of the erythrocyte, and the Duffy blood group system are involved in a step in invasion after initial attachment.

\section{METHODS}

Production of monoclonal antibodies. Erythrocytes infected with $P$. knowlesi (H strain) (8) were obtained from 
infected rhesus monkeys. When the parasitemia was 5-20\% and the majority of schizonts contained more than six nuclei, heparinized blood was drawn and placed over glass beads to remove platelets and some leukocytes. The packed erythrocytes were placed in $2 \times 100-\mathrm{mm}$ glass tubes and then centrifuged $10 \mathrm{~min}$ at $1,300 \mathrm{~g}$. The tube was broken at the interface between the low density schizont-infected erythrocytes and normal erythrocytes. The infected erythrocytes were collected and used for immunization. A BALB/c mouse was immunized intravenously with $10^{8}$ schizont-infected erythrocytes and 0.167 opacity units of Bordetella pertussis $\left(\sim 10^{8}\right.$ organisms), followed by three weekly boosts of $10^{8}$ schizont-infected erythrocytes intravenously without $B$. pertussis. The $B$. pertussis was inactivated with $0.01 \%$ thimerosal and freeze-dried for storage as lot $7 \mathrm{~b}$. We obtained $B$. pertussis from Dr. Charles R. Manclark, National Center for Drugs and Biologics, Bethesda, MD 20205 (available to other scientists on request from Dr. Manclark).

$3 \mathrm{~d}$ after the last immunization, spleen cells were fused with the NS-1 myeloma line, a nonsecreting clone of P3x63Ag8, according to the procedure described by Köhler and Milstein (9) and Galfre et al. (10). After the cells were grown overnight in HT selective media, they were plated into two 24-well Costar plates (Costar, Data Packaging, Cambridge, MA). When heavy growth had occurred 2 wk later, the cells were inoculated into pristane-primed mice and were grown as ascites tumors.

Ascites fluid from each mouse was screened for blocking invasion of $\boldsymbol{P}$. knowlesi to rhesus erythrocytes. The cells from one ascites that blocked invasion were cloned (A9) and recloned (A9D3) by limit dilution. Five A9 subclones tested had the same erythrocyte specificity by immunoprecipitation and inhibition of invasion. Therefore, A9 was probably a clone. The studies in the present paper were performed on A9 and one of the A9 subclones, A9D3. The monoclonal antibody A9D3 was of the IgG2a subclass.

Immunoglobulin $(I g)$ purification and preparation of Fab fragments. Ig purification of A9D3 was achieved by passing the ascites over a column of protein $A$ coupled to Sepharose 4B (Pharmacia, Uppsala, Sweden) according to Ey et al. (11) and eluting the bound subclasses of $\mathrm{Ig}$ with a linear $\mathrm{pH}$ gradient as previously described (12). The fractions containing IgG2a were pooled and concentrated by Amicon filtration with a PM 10 filter (Amicon Corp., Scientific Systems Div., Lexington, MA). Immunoelectrophoretic analysis demonstrated that the fraction contained only IgG2a that was primarily of hybridoma origin (i.e., only a single symmetrical arc was observed); IgG2a of host origin (i.e., a broad asymmetrical arc) was not observed. Purified hybridoma A9D3 was dialyzed against buffer containing cysteine and Fab fragments were prepared by papain treatment according to Porter (13), except digestion was limited to $1.5 \mathrm{~h}$. The resulting mixture was dialyzed against Tris- $\mathrm{HCl}, \mathrm{pH} 8.0$, and then passed over a column of protein A-Sepharose to remove any undigested, intact IgG and the Fc portion resulting from digestion. The eluate of $\mathrm{Fab}$ fragments was concentrated by Amicon filtration and further purified on a G200 molecular sizing column. Purity of each fraction was assessed under nonreducing conditions by sodium dodecyl sulfate-polyacrylamide gel electrophoresis (SDS-PAGE) ${ }^{1}$ on $10 \%$ polyacrylamide gels.

${ }^{1}$ Abbreviations used in this paper: DMSO, dimethyl sulfoxide; PAGE, polyacrylamide gel electrophoresis; PBST, phosphate-buffered saline with $0.5 \%$ Triton X-100; PDP, pyridoxal phosphate.
An IgG2a monoclonal antibody (D5), which had no reactivity with parasites or erythrocytes, was processed in parallel with A9D3 as our control for nonspecific toxicity.

Erythrocyte agglutination assay. Two drops of ascites, purified IgG or Fab fragments of IgG at various dilutions were added to one drop of a $2 \%$ erythrocyte suspension. The cells were incubated at $37^{\circ} \mathrm{C}$ for $30 \mathrm{~min}$, centrifuged for 15 $s$ in an Immufuge (Dade Div., American Hospital Supply Corp., Miami, FL) (1,000 g) and observed for direct agglutination. The cells were then washed three times with phosphate-buffered saline (PBS) $/ 0.01 \%$ albumin. Goat anti-mouse IgG purified on a column of mouse lambda was added and the cells were immediately centrifuged for $30 \mathrm{~s}$ in an Immunofuge. The pellet was observed for macroscopic and microscopic agglutination.

Assay for blocking invasion. An assay of erythrocyte invasion was performed with merozoites rupturing from mature schizont-infected erythrocytes in culture. A mixture of $50 \mu \mathrm{l}$ of schizont-infected erythrocytes $\left(10^{7} / \mathrm{ml}\right)$ and $50 \mu \mathrm{l}$ of erythrocytes $\left(10^{8} / \mathrm{ml}\right)$ from a normal rhesus monkey was incubated in the presence of antibody in $400 \mu \mathrm{l}$ of culture medium (RPMI 1640 containing $11 \mathrm{mM}$ glucose; $27 \mathrm{mM}$ $\mathrm{NaHCO}_{3} ; 30 \mathrm{mM}$ Hepes (pH 7.4), and $10 \%$ fetal calf serum) gassed with $6 \% \mathrm{CO}_{2}, 3 \% \mathrm{O}_{2}$, and $91 \% \mathrm{~N}_{2}$. The cells were rocked continuously with a Dade aliquot mixer (Dade Div. American Hospital Supply Corp.) for $3 \mathrm{~h}$ at $37^{\circ} \mathrm{C}$. To determine the erythrocyte invasion rate, the cells were washed once with $100 \%$ fetal calf serum, pelleted, spread in a thin film, and stained with Giemsa. The percentage of erythrocytes infected with ring forms, the young parasites, was determined.

To test the effects of Fab fragments on invasion, erythrocytes were preincubated with $1 \mathrm{ml}$ of Fab fragments at a dilution of 1:10 in PBS per 107 erythrocytes for $30 \mathrm{~min}$ at $37^{\circ} \mathrm{C}$. The cells were centrifuged at $500 \mathrm{~g}$ for $5 \mathrm{~min}$ and added to the invasion assay with various dilutions of fresh Fab fragments.

In some experiments the Fab fragments were preabsorbed with human and rhesus erythrocytes to determine their effects on invasion.

Attachment assay. Schizont-infected erythrocytes as purified above were cultured at $2 \times 10^{7}$ parasitized erythrocytes $/ \mathrm{ml}$ with $50 \mu \mathrm{g} / \mathrm{ml}$ chymostatin (Sigma Chemical Co., St. Louis, MO) and $50 \mu \mathrm{g} / \mathrm{ml}$ leupeptin (Boehringer Mannhein Biochemicals, Indianapolis, IN). Chymostatin was dissolved in dimethyl sulfoxide (DMSO); the final concentration of DMSO in culture was $0.5 \%$. Leupeptin was dissolved in RPMI 1640. After $\sim 3 \mathrm{~h}$ in culture at $37^{\circ} \mathrm{C}, 5 \mathrm{ml}$ of culture was centrifuged at $900 \mathrm{~g}$ for $5 \mathrm{~min}$ and resuspended in $1 \mathrm{ml}$ of RPMI 1640 to which $10 \mu \mathrm{l}$ of rabbit anti-rhesus erythrocyte serum was added (agglutination titer, 1:2,500). The sample was shaken intermittently at room temperature for $5 \mathrm{~min}$, then centrifuged at $1,000 \mathrm{~g}$ in an Immunofuge and the agglutinated pellet was washed with $4 \mathrm{ml}$ RPMI 1640 . Merozoites were released by the addition of $1 \mathrm{ml}$ of RPMI to the pellet and by forcing the sample 10 times through a 25-gauge needle with a $1-\mathrm{ml}$ syringe. The sample was then passed sequentially over two $4 \times 0.5-\mathrm{cm}$ columns of protein A-Sepharose CL-4B (Pharmacia) to remove the unruptured schizont-infected erythrocytes and erythrocyte membranes. The RPMI 1640 eluant consisted of free invasive merozoites. Attachment assays were done as previously described (7). Briefly, cytochalasin B (Aldrich Chemical Co., Milwaukee, WI) in DMSO was added to $0.5 \mathrm{ml}$ of merozoites to give a final concentration of cytochalasin B of $10 \mu \mathrm{g} / \mathrm{ml}$ in $0.1 \%$ DMSO. Rhesus erythrocytes at $10^{8} / \mathrm{ml}$ in complete media with $10 \%$ fetal calf serum were preincubated for 5 min with the appropriate monoclonal antibody or control (monoclonal 
antibody 709) at dilutions stated in Table II. $50 \mu$ l of erythrocytes were added to $0.5 \mathrm{ml}$ of the merozoite suspension to which the monoclonal antibody was added. The samples were agitated for $10 \mathrm{~min}$ at $37^{\circ} \mathrm{C}$. The samples were fixed with an equal volume of $4 \%$ glutaraldehyde in $0.15 \mathrm{M} \mathrm{NaCl}$, $10 \mathrm{mM}$ sodium phosphate, $\mathrm{pH}$ 7.4. Rates of attachment were quantified by counting the number of merozoites attached per 1,000 erythrocytes.

Radioiodination of erythrocytes (14). $5 \times 10^{8}$ freshly drawn rhesus erythrocytes were washed five times with PBS $\mathrm{pH}$ 7.4. The cells were resuspended in 1,000 $\mu \mathrm{l}$ PBS to which was added $50 \mu$ l lactoperoxidase in PBS $(1 \mathrm{mg} / \mathrm{ml}), 300 \mu \mathrm{Ci}$ carrier-free $\mathrm{Na}^{125} \mathrm{I}(1.7 \mathrm{Ci} / \mathrm{mg}$ ) (New England Nuclear, Boston, MA), and $50 \mu \mathrm{l}$ hydrogen peroxide $(0.0006 \%$ in $\mathrm{PBS})$. $50 \mu \mathrm{l}$ hydrogen peroxide was added four times at $1-\mathrm{min}$ intervals. The cells were washed three times in PBS.

Radiolabeling of erythrocytes with periodate and $\mathrm{NaB}^{3} \mathrm{H}_{4}$ (15). $10^{9}$ Freshly drawn rhesus erythrocytes were washed five times with PBS. The cells were resuspended in $100 \mu \mathrm{l}$ PBS containing $2 \mathrm{mM} \mathrm{IO}_{4}$, and stored in the dark on ice for $20 \mathrm{~min}$. The cells were washed two times with PBS, resuspended in $2 \mathrm{ml}$ PBS containing $20 \mathrm{mCi} \mathrm{NaB}^{3} \mathrm{H}_{4}$, and stored in the dark on ice for $20 \mathrm{~min}$. The cells were then washed three times with PBS.

Radiolabeling of erythrocytes with pyridoxal phosphate (PDP) (16). Human and monkey erythrocytes were washed $10 \mathrm{mM}$ Hepes, $\mathrm{pH} 7.4,150 \mathrm{mM} \mathrm{NaCl}$. After removal of the supernatant, $100 \mu \mathrm{l}$ of $10 \mathrm{mM}$ PDP in Hepes (7.4)/ $\mathrm{NaCl}$ was added to the pellet containing $5 \times 10^{8}$ cells. The PDP-cell suspension was incubated for $20 \mathrm{~min}$ at $37^{\circ} \mathrm{C}$ in the dark. The cells were washed twice with Hepes $(\mathrm{pH} \mathrm{8.0)} / \mathrm{NaCl}$ at $4^{\circ} \mathrm{C}$. The cells were resuspended in $0.5 \mathrm{ml}$ Hepes $(\mathrm{pH} 8.0) /$ $\mathrm{NaCl}$ at $0^{\circ} \mathrm{C}$. $20 \mu \mathrm{l}$ of $\mathrm{NaB}^{3} \mathrm{H}_{4}(5.0 \mathrm{Ci} / \mathrm{mmol}$, The Radiochemical Center, Amersham Corp., Arlington Heights, IL) $(10 \mathrm{mCi})$ in $0.01 \mathrm{~N} \mathrm{NaOH}$ was added, The sample mixed, and incubated for $30 \mathrm{~min}$ at $0^{\circ} \mathrm{C}$ in the dark. The cells were washed in cold PBS and extracted with $1 \%$ Triton X-100.

Detergent extraction of labeled cells. Erythrocytes labeled with ${ }^{125} \mathrm{I}$ or ${ }^{3} \mathrm{H}$ were suspended in $1 \mathrm{ml}$ PBS containing $1 \%$ Triton X-100 and protease inhibitors $2 \mathrm{mM}$ phenyl-methylsulphonyl fluoride, $1 \mathrm{mM} p$-tosyl-2-lysine chloromethyl ketone, and $1 \mathrm{mM}$ EDTA (Sigma Chemical Co.). The suspensions were incubated on ice for $1 \mathrm{~h}$ with intermittent mixing and centrifuged at $12,000 \mathrm{~g}$ for $15 \mathrm{~min}$ at room temperature in an Eppendorf centrifuge 5412. Soluble extracts were stored at $-70^{\circ} \mathrm{C}$ and used for studies described below.

Immunoprecipitation. $100 \mu$ l-labeled extracts of rhesus or human erythrocytes were preadsorbed with $100 \mu \mathrm{l}$ of $50 \%$ vol/vol protein A-Sepharose CL-4B (Pharmacia) that had been washed with PBS containing $1 \%$ Triton X-100. $2 \times 10^{5}$ cpm of preadsorbed ${ }^{125}$ I-rhesus erythrocyte extract, $1 \times 10^{6}$ cpm of the preadsorbed ${ }^{3} \mathrm{H}$-rhesus erythrocyte extract labeled with periodate $/ \mathrm{NaB}^{3} \mathrm{H}_{4}$, or $3 \times 10^{5} \mathrm{cpm}$ of the preadsorbed rhesus or human erythrocyte extracts labeled with PDP were mixed with $5 \mu \mathrm{l}$ of ascites fluid containing the monoclonal antibody (A9D3 in a total volume of $100 \mu 1$ PBS containing $0.5 \%$ Triton X-100 [PBST]). Ascites fluid induced by myeloma line P3 $\times 63$ was used as a control. Mixtures were incubated for $45 \mathrm{~min}$ at room temperature on a Dade aliquot mixer (Dade, Div., American Hospital Supply Corp.). $100 \mu \mathrm{l}(50 \% \mathrm{vol} / \mathrm{vol})$ protein A-Sepharose was added to each tube and incubation was continued for an additional $45 \mathrm{~min}$. All tubes were washed twice with $3 \mathrm{ml}$ PBST containing $10 \%$ fetal bovine serum, followed by one wash with PBST containing $0.65 \mathrm{M}$ sodium chloride. After two final washes with PBST, the protein A-Sepharose beads were transferred to 1.5 ml Eppendorf tubes.

Immune complexes were eluted from protein A-Sepharose by incubating them with $100 \mu$ l electrophoresis sample buffer for $30 \mathrm{~min}$ at $56^{\circ} \mathrm{C}$. The sample buffer contained $5 \%$ SDS; $62.5 \mathrm{mM}$ Tris- $\mathrm{HCl}, \mathrm{pH} 6.8 ; 10 \%$ glycerol; $0.001 \%$ bromophenol blue; and $2 \% 2-\beta$-mercaptoethanol. Eluates were electrophoresed on 5-15\% polyacrylamide gradient slab gels as described by Laemmli (17). The gels were fixed in $10 \%$ trichloroacetic acid, stained with Coomassie Blue R-250, and prepared for autoradiography or fluorography (18). Standard molecular weight markers included myosin, $\beta$-galactosidase, phosphorylase $B$, bovine serum albumin, and ovalbumin $(200,116,94,66$, and 45 kD, respectively; Bio-Rad Laboratories, Richmond, CA).

Immunoabsorption of band 3. Rhesus erythrocytes were labeled as above by lactoperoxidase catalyzed radioiodination. The cells were lysed by adding $40 \mathrm{vol}$ of $5 \mathrm{mM}$ sodium phosphate, $\mathrm{pH} 8.0$, to 1 vol of packed erythrocytes at $4^{\circ} \mathrm{C}$. The ghosts were washed three times with $5 \mathrm{mM}$ sodium phosphate, $\mathrm{pH} 8.0$, at $4^{\circ} \mathrm{C}$ and extracted in $1 \%$ Triton X-100 (5 $\times 10^{8}$ ghosts $/ \mathrm{ml}$ Triton $\mathrm{X}-100$ ). After $1 \mathrm{~h}$ at $4^{\circ} \mathrm{C}$, the erythrocyte skeleton was removed by centrifugation at $48,000 \mathrm{~g}$ for $10 \mathrm{~min}$. The supernatant was used for immunoabsorption.

$0.5 \mathrm{ml}$ of ascites containing monoclonal antibody A9 was incubated with $0.2 \mathrm{ml}$ of protein A-Sepharose for $1 \mathrm{~h}$. The beads were washed three times to remove unbound material from the ascites. The labeled, Triton-extracted ghosts (75 $\mu l)$ were incubated with the protein A-Sepharose for $18 \mathrm{~h}$ at $4^{\circ} \mathrm{C}$. The unbound supernatant was then added for $1 \mathrm{~h}$ to $40 \mu \mathrm{l}$ of protein A-Sepharose that had no antibody bound. This step was to remove any immune complexes that had come off the beads during the first step of absorption with A9-protein A-Sepharose. The supernatant from the second step of absorption was run on SDS-PAGE. The control was run parallel and used another IgG2a monoclonal antibody that did not react with rhesus erythrocytes (13C11).

Assay of sulfate exchange in the presence of monoclonal antibodies $A 9$ and $A 9 D 3$. Loading procedure and rate of exchange of sulfate in erythrocytes was determined according to Schnell et al. (19). Freshly drawn rhesus and human blood were washed five times with $\mathrm{PBS}, \mathrm{pH}$ 7.4. To exchange the intracellular ion content of erythrocytes with sulfate, cells were resuspended in sulfate buffer containing $110 \mathrm{mM}$ $\mathrm{Na}_{2} \mathrm{SO}_{4}$ and $20 \mathrm{mM}$ Hepes, $\mathrm{pH}$ 6.4. The suspension, at a cell concentration of $20 \%$, was incubated at $37^{\circ} \mathrm{C}$ for $30 \mathrm{~min}$. The cells were then washed, resuspended in the same buffer and incubated as above. The cell suspension was then concentrated to a $40 \%$ hematocrit in a final volume of $15 \mathrm{ml}$. The loading procedure was started by the addition of 300 $\mu \mathrm{Ci}\left[{ }^{35} \mathrm{~S}^{2} \mathrm{Na}_{2} \mathrm{SO}_{4}\right.$. Cells were incubated at $37^{\circ} \mathrm{C}$ for $1 \mathrm{~h}$. The loaded cells were then pooled and washed four times in 20 vol of sulfate buffer. Cells were packed and stored in ice for further use. Monoclonal antibodies A9 and A9D3 were added at the dilution of $1: 100$ to $1: 1,000$ and incubated for $1 \mathrm{~h}$ at $4^{\circ} \mathrm{C}$.

Exchange assay was begun by diluting $125 \mu \mathrm{l}$ of the above packed cells into $10 \mathrm{ml}$ of sulfate buffer at $30^{\circ} \mathrm{C}$, containing the antibodies at the same dilutions. At 2-min intervals, 0.5 $\mathrm{ml}$ of the above suspension was withdrawn into precooled polyethylene microfuge test tubes. The suspensions were then centrifuged and the supernatants were assayed for radioactivity, using Aquasol scintillation fluid (New England Nuclear).

\section{RESULTS}

Monoclonal antibody A9 directly agglutinated rhesus erythrocytes with a titer of 1:100; A9D3, a subclone of $\mathrm{A9}$, caused no direct agglutination at a 1:10 dilution. 
TABLE I

Effect of Anti-Rhesus Erythrocyte Monoclonal Antibodies A9 and A9D3 and an Unrelated Monoclonal Antibody (D5) on Invasion of Rhesus and Human Erythrocytes by P. knowlesi Merozoites

\begin{tabular}{|c|c|c|c|c|c|c|c|c|c|c|c|}
\hline & \multirow{2}{*}{$\begin{array}{l}\text { Rhesus } \\
\text { erythrocyte } \\
\text { agglut- } \\
\text { nation }\end{array}$} & \multicolumn{5}{|c|}{ Invasion of rhesus erythrocytes } & \multicolumn{5}{|c|}{ Invasion of human erythrocytes" } \\
\hline & & $1: 20 t$ & $1: 40$ & $1: 100$ & $1: 1,000$ & $1 ; 10,000$ & $1: 201$ & 1:40 & $1: 100$ & 1:1,000 & $1: 10,000$ \\
\hline & & \multicolumn{10}{|c|}{$\%$ of control } \\
\hline A9 ascites & $1: 10^{7}$ & ND & ND & 27 & 10 & 23 & ND & ND & 78 & 88 & 97 \\
\hline A9D3 ascites & $1: 10^{6}$ & ND & ND & 34 & 55 & 138 & ND & ND & 104 & 86 & 75 \\
\hline \multirow{2}{*}{\multicolumn{12}{|c|}{$\begin{array}{l}\text { A9D3 purified } \S \\
(3.0 \mathrm{mg} / \mathrm{ml})\end{array}$}} \\
\hline & $1: 10^{6}$ & 36 & 23 & 49 & 86 & 98 & 82 & 76 & 95 & 98 & 113 \\
\hline \multicolumn{12}{|l|}{ D5 purified $\S$} \\
\hline$(3.0 \mathrm{mg} / \mathrm{ml})$ & & 143 & 131 & 62 & 118 & 96 & 84 & 78 & 90 & 106 & 115 \\
\hline
\end{tabular}

ND, not done.

- The control invasion rates were 6.7 and $26 \%$ for human and rhesus erythrocytes, respectively.

t Dilution of antisera for the invasion assay.

\$ The monoclonal antibodies (IgG) were purified on a protein A-Sepharose column.

The indirect agglutination titers for A9 and A9D3 with goat anti-mouse Ig were $1: 10^{6}$ and $1: 10^{5}$, respectively. A9 also agglutinated erythrocytes of another Old World monkey, Macaca fascicularis (the kra monkey), at a titer of $>1: 10^{5}$ (indirect agglutination titer). A9 did not agglutinate human, chimpanzee, or Aotus trivirgatus (a New World monkey) erythrocytes when tested at a titer of 1:10 by the direct or indirect agglutination test. Thus, the monoclonal antibody appeared specific for a determinant on Old World monkey erythrocytes.

Both A9 and A9D3 inhibited invasion of $P$. knowlesi merozoites into rhesus erythrocytes (Tables I and II). Attachment rates performed with cytochalasin-treated merozoites were similar in the presence or absence of antibody (Table II). Erythrocytes with attached merozoites appeared different, however, in the presence of antibody as compared with the controls. Erythrocytes in the absence of antibody became swollen (data not shown) and crenated (Table II). These morphologic changes were rarely observed in antibody-coated erythrocytes.

It was important to demonstrate that the reduced invasion in the presence of monoclonal antibody did not result from an antibody effect on schizont-infected erythrocytes or from nonspecific toxic factors. The invasion assay is performed by mixing schizont-infected erythrocytes as a source of merozoites with normal host erythrocytes and antibody. The schizont within the erythrocyte must reach full maturation by forming individual, healthy merozoites; the merozoites must be released from the erythrocyte at the time of erythrocyte lysis; and the extracellular merozoites must remain healthy until they contact and invade a host erythrocyte. Toxic factors may interfere nonspecifi- cally with any of the steps. To test for nonspecific effects, we studied invasion of human erythrocytes in parallel with studies of rhesus erythrocytes, since the monoclonal antibody does not bind to human cells. A9 and A9D3 inhibited invasion of monkey erythrocytes at high dilutions of antibody (Table I). In comparison, the effect on invasion of human erythrocytes was minimal and variable as the sera were diluted. Furthermore, D5, a control monoclonal antibody that had no antibody activity against erythrocytes or parasites caused the same small reduction in invasion of human

TABLE II

Effect of Anti-Rhesus Erythrocyte Monoclonal Antibodies $A 9$ and A9D3 and an Unrelated Monoclonal Antibody

(709) on Attachment of Cytochalasin-treated Merozoites to Rhesus Erythrocytes

\begin{tabular}{lccr}
\hline & \multicolumn{2}{c}{ Attachment } \\
\cline { 2 - 3 } & $\begin{array}{c}\text { Merozoites per } \\
1,000 \text { erythrocytes }\end{array}$ & Crenation & Invasiont \\
\hline & & $\%$ & $\%$ \\
A9 ascites, $1 ; 1,000$ & 150 & 0.3 & 1.8 \\
A9D3 ascites, $1: 100$ & 131 & 0 & 2.8 \\
709 ascites, $1: 100$ & 151 & 7 & 15.8 \\
709 ascites, $1: 1,000$ & 138 & 11 & ND \\
Medium & 134 & 13 & 17.6 \\
\hline
\end{tabular}

ND, not done.

- Percentage of erythrocytes with merozoites attached that crenated.

$\downarrow$ Invasion and attachment were performed simultaneously. However, the merozoites for invasion were not treated with cytochalasin. Invasion is expressed as the percentage of erythrocytes infected with ring forms. 
erythrocytes. As further evidence for specific inhibition of invasion, we found that A9D3 ascites preabsorbed with rhesus erythrocytes had no inhibitory effect on invasion. The fact that $A 9$ ascites was active at higher dilutions than A9D3 was a consistent finding in other experiments (data not shown) and correlated with the higher agglutination titer of this ascites. We also tested the invasion rate of erythrocytes coated with antibody and then washed so that the concentration of toxic substances or free antibody that was available to interact with schizont-infected erythrocytes or merozoites would be greatly reduced. The invasion rate of these antibody-coated erythrocytes was reduced (Data not shown). We conclude that the monoclonal antibody acted specifically to inhibit invasion by binding to an erythrocyte determinate; toxicity to the parasite was excluded by these experiments.

Although it was evident that the antibody effect was specific for rhesus erythrocytes, the antibody may have caused an indirect effect on invasion by cross-linking determinates on the erythrocyte surface. This crosslinking could cause reorganization of membrane components, cover unrelated determinates, and even cause indirect effects on the cytoskeleton. We therefore tested Fab fragments of A9D3 for their effect on invasion. We purified the Fab fragments on a G200 column to decrease nonspecific toxic effects and to remove any undigested IgG. The column-purified Fab was enriched in that protein over other proteins and contained no $F\left(a b^{\prime}\right)_{2}$ or IgG.

The A9D3 monovalent Fab fraction agglutinated rhesus erythrocytes in the indirect Coombs reaction and inhibited invasion of rhesus erythrocytes (Table III). Evidence that the effect of A9D3 Fab was specific were threefold. First, A9D3 Fab preabsorbed with rhesus erythrocytes had no inhibitory activity; A9D3 Fab preabsorbed with human erythrocytes had full inhibitory activity. As would be expected, Fab preabsorbed with rhesus erythrocytes no longer agglutinated rhesus erythrocytes. Fab preabsorbed with human erythrocytes had the same titer $\left(1: 10^{3}\right.$ as unabsorbed Fab (Table III). Therefore, only rhesus erythrocytes could remove the inhibitory activity from the A9D3 Fab. Second, the column-purified A9D3 Fab had no inhibitory activity against invasion of human erythrocytes. If the Fab had been toxic to the parasite, the invasion of human erythrocytes would have been suppressed. Third, the D5 Fab, an antibody with no antierythrocyte or antiparasite activity, had no effect on invasion of rhesus erythrocytes.

The erythrocyte component to which the monoclonal antibody was directed was determined by immunoprecipitation of erythrocyte surface components solubilized in Triton X-100. Only band 3 was immunoprecipitated from $\mathrm{PDP} / \mathrm{NaB}^{3} \mathrm{H}_{4}$-labeled rhesus erythrocytes; no proteins were precipitated from hu-

TABLE III

Effect of Fab Fragments of Monoclonal Antibodies A9D3 and D5 on Invasion of Rhesus and Human Erythrocytes by P. knowlesi Merozoites

\begin{tabular}{|c|c|c|c|c|}
\hline Antibody & $\begin{array}{c}\text { Rhesus } \\
\text { erythrocytes } \\
\text { agglutination titer }\end{array}$ & $\begin{array}{l}\text { Dilution of } \\
\text { antibody }\end{array}$ & $\begin{array}{l}\text { Invasion of rhesus } \\
\text { erythrocytes }\end{array}$ & $\begin{array}{l}\text { Invasion of human } \\
\text { erythrocytes }\end{array}$ \\
\hline & & & \multicolumn{2}{|c|}{$\%$ of control } \\
\hline \multirow[t]{2}{*}{ D3 Fab $(1.4 \mathrm{mg} / \mathrm{ml})$} & \multirow[t]{2}{*}{$1: 10^{3}$} & $1: 20$ & $43 \pm 2.2 \quad(4) !$ & $76 \pm 12.3(4)$ \\
\hline & & $1: 40$ & $50 \pm 3.3$ & $95 \pm 5.9$ \\
\hline \multirow[t]{2}{*}{ Purified D3 Fab\$ $(1.1 \mathrm{mg} / \mathrm{ml})$} & \multirow[t]{2}{*}{$1: 10^{3}$} & $1: 20$ & $49 \pm 10.5(2)$ & $96 \pm 10.5(2)$ \\
\hline & & $1: 40$ & $53 \pm 6.5$ & $104 \pm 7.5$ \\
\hline \multirow{2}{*}{$\begin{array}{l}\text { Purified D3 Fab preabsorbed } \\
\text { with rhesus erythrocytes }\end{array}$} & \multirow[t]{2}{*}{$<1: 10$} & $1: 20$ & $109 \pm 14.0(2)$ & $89 \pm 5.0$ \\
\hline & & $1: 40$ & $97 \pm 2.9$ & $86 \pm 1.9$ \\
\hline \multirow{2}{*}{$\begin{array}{l}\text { Purified D3 Fab preabsorbed } \\
\text { with human erythrocytes" }\end{array}$} & \multirow[t]{2}{*}{$1: 10^{3}$} & $1: 20$ & $50 \pm 5.5$ & $84 \pm 4.0$ \\
\hline & & $1: 40$ & $57 \pm 4.2$ & $93 \pm 9.3$ \\
\hline \multirow[t]{2}{*}{ D3 Fab $(0.23 \mathrm{mg} / \mathrm{ml})$} & \multirow[t]{2}{*}{$<1: 10$} & $1: 20$ & $96 \pm 4.1$ & $100 \pm 9.7$ \\
\hline & & $1: 40$ & $95 \pm 2.2$ & $96 \pm 7.9$ \\
\hline
\end{tabular}

\footnotetext{
- The control invasion rates were 4.5 and $9.5 \%$ for human erythrocytes and 27 and $35 \%$ for rhesus erythrocytes, respectively.

† Data represent mean \pm SE. The number of experiments for each condition is given in parentheses. \& A9D3 Fab was purified on a G200 column.

"The purified A9D3 Fab was absorbed with rhesus or human erythrocytes before use in the invasion assay.
} 


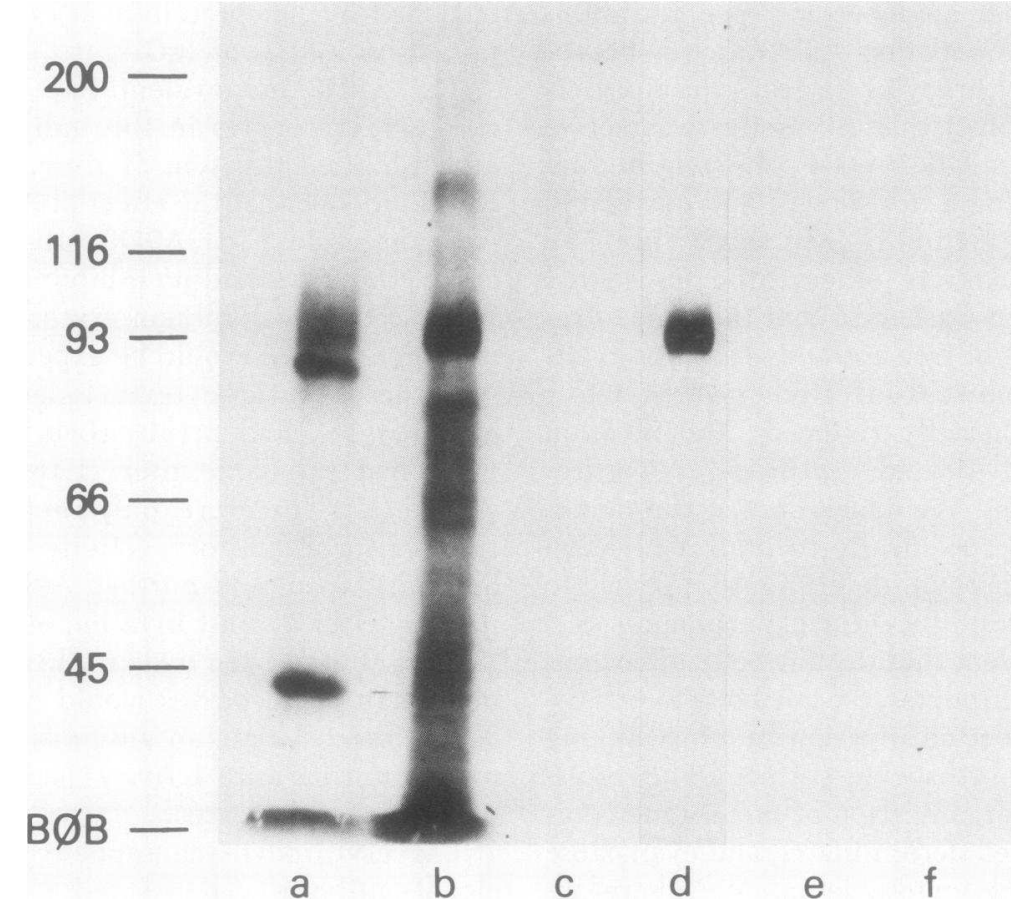

FIgURE 1 Fluorogram of SDS-PAGE of PDP/ $\mathrm{NaB}^{3} \mathrm{H}_{4}$-labeled human $(a)$ and rhesus $(b)$ erythrocytes. Band 3 is the broad band with an $M_{r}$ of $\sim 97,000$. Triton X-100 extracts of labeled human $(c$ and $e$ ) and rhesus $(d$ and $b$ ) erythrocytes were incubated with monoclonal antibody A9D3 $(c$ and $d$ ) and myeloma ascites control $(e$ and $f)$. Note the specific precipitation of rhesus band 3 in lane $d$. The bromophenol blue dye front (BØB) and molecular weight standards are marked on the left side of the figure.

man erythrocytes labeled in parallel (Fig. 1). Band 3 was also immunoprecipitated from rhesus erythrocytes labeled by lactoperoxidase-catalyzed radioiodination (data not shown). Rhesus erythrocyte sialoglycoproteins labeled with periodate $/ \mathrm{NaB}^{3} \mathrm{H}_{4}$ were not immunoprecipitated by A9D3.

Further evidence that $A 9$ recognized an epitope on band 3 was the immunoabsorption of band 3 from Triton X-100-extracted ghosts. Ghosts of erythrocytes labeled by lactoperoxidase-catalzyed radioiodination and extracted with Triton X-100 were absorbed with A9-protein A-Sepharose or a control IgG2a monoclonal antibody bound to protein A-Sepharose. Band 3 and a broad band with an $M_{\mathrm{r}}$ of $\sim 200,000$, a band 3 dimer (see Discussion), was specifically removed by A9 (Fig. 2). A minor sharp band that comigrated with the upper part of band 3 was not removed.

Since band 3 functions in anion transport, it was possible that the effect of antibody on invasion was caused by an indirect effect on transport. Two studies excluded this possibility. First, we treated rhesus erythrocytes with $50 \mu \mathrm{M}$ DIDS $(4,4$ '-diisothiocyano2,2'-disulfonic acid stilbene, Pierce Chemical Co., Rockford, IL). Although sulfate exchange was blocked, DIDS-treated erythrocytes were invaded normally.
Second, monoclonal antibodies A9 and A9D3 had no effect on anion transport as measured by $\mathrm{Na}_{2} \mathrm{SO}_{4}$ exchange of antibody-coated rhesus erythrocytes.

\section{DISCUSSION}

We identified a monoclonal antibody specific for band 3 of rhesus erythrocyte membranes that inhibited invasion of these erythrocytes by $P$. knowlesi merozoites. The evidence that the monoclonal antibody recognized an epitope on rhesus erythrocyte band 3 was twofold. First, the monoclonal antibody immunoprecipitated band 3 from Triton X-100 extracts of rhesus erythrocytes labeled by $\mathrm{PDP} / \mathrm{NaB}^{3} \mathrm{H}_{4}$ and by lactoperoxidase-catalyzed radioiodination. Second, the monoclonal antibody bound to protein A-Sepharose removed band 3 and a broad band with an $M_{\mathrm{r}}$ of $\sim 200,000$. This $M_{\mathrm{r}}-200,000$ protein is probably a band-3 dimer, as purified band 3 in Triton X-100 forms aggregates that are resistant to SDS (see Fig. $2 C$ in reference 20). Since the band-3 dimer is completely removed, it is likely that the unabsorbed sharp band in the upper part of the band 3 region is a comigrating protein unrelated to band 3 .

The effect was specific and not caused by nonspecific 


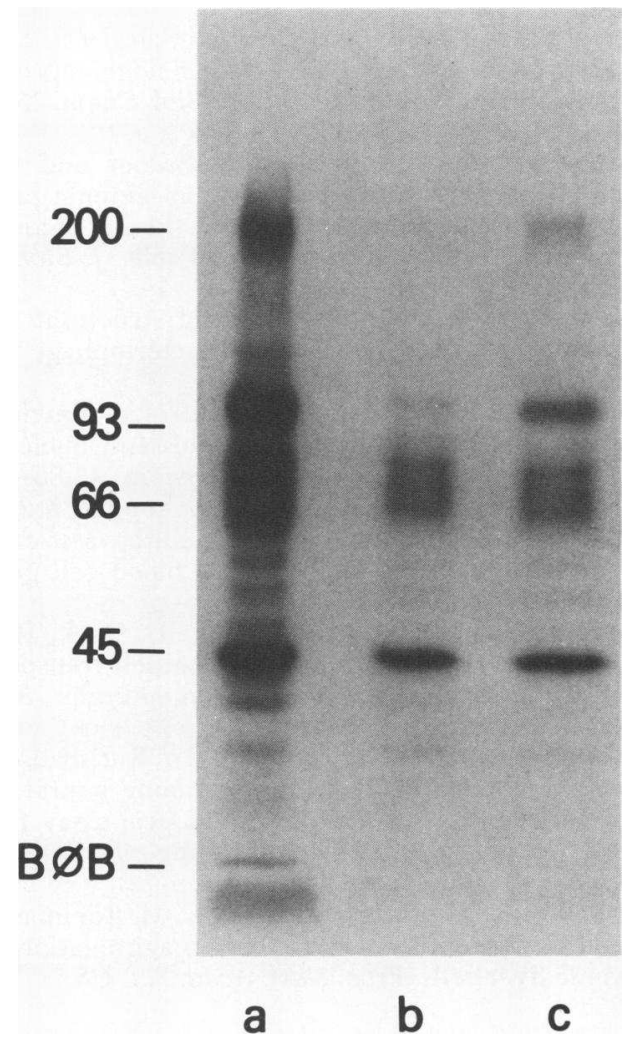

Figure 2 Autoradiogram of SDS-PAGE of Triton X-100extracted rhesus erythrocyte ghosts labeled as intact cells by lactoperoxidase-catalyzed radioiodination $(a)$. The Triton X100 extract was immunoabsorbed with monoclonal antibody A9 bound to protein A-Sepharose (b) or with a control IgG 2a monoclonal antibody bound to protein A-Sepharose (c). Molecular weight standards as in Fig. 1.

toxic effects on the parasite, since preabsorption with rhesus erythrocytes removed the inhibitory activity. Absorption with human erythrocytes did not reduce the invasion blocking effect of the sera. Furthermore, column-purified Fab fragments of A9D3 that inhibited invasion of rhesus erythrocytes had no effect on invasion of human erythrocytes. Since the antibody was specific for Old World monkey erythrocytes, the failure to affect invasion of human erythrocytes indicated that the purified Fab was not toxic.

Fab fragments of polyspecific antisera have been used to identify receptors for cell-cell recognition in various developmental systems (21-23). The assumption in these studies has been that although the antibody is directed against many components on the surface, only those binding to the receptor component will inhibit cell-cell interaction. We are making a similar assumption in the malaria system that, if a monoclonal Fab fragment inhibits invasion, it is bound to a component involved in invasion.

The invasion process follows a sequence that in- cludes initial attachment between any part of the merozoite and the erythrocyte (1), reorientation to apical attachment (7), junction formation between the apical end of the merozoite and the erythrocyte (2), formation of a parasitophorous vacuole continuous with the erythrocyte membrane (24), movement of the junction around the merozoite bringing the merozoite into the vacuole (2), and sealing of the vacuole at its orifice. We have now identified two erythrocyte surface determinants involved in invasion of erythrocytes by $P$. knowlesi: the Duffy blood group system (see reference 25 for review) and band 3. The Duffy blood group system is believed to be involved in junction formation, since the recognition and apical reorientation is identical for both Duffy-positive human erythrocytes and Duffy-negative erythrocytes (7). Junction formation and invasion does not occur, however, with Duffy-negative human erythrocytes (7). Definition of the role for band 3 in the complex interaction between parasite and erythrocyte during invasion is unknown. It should be noted that, as in the case of Duffy-negative human erythrocytes (7), antibodies to rhesus erythrocyte band 3 had no effect on the attachment rate. Antibodycoated cells, however, rarely swelled after attachment, a common occurence in control cells. This may reflect abnormalities in the subsequent steps in invasion: junction formation and the creation of a vacuole.

Previous observations on the invasion process may relate to band 3 . First, chymotrypsin that cleaves band 3 (26) completely blocks invasion of $P$. knowlesi into human erythrocytes (5). Furthermore, on direct observation, no attachment, deformation, or interaction of any kind occurred between merozoites and chymotrypsin-treated human erythrocytes (1). The relation of this observation to band 3 is complicated by the fact that chymotrypsin also destroys Duffy a and Duffy $b$ activity (6). The second observation was the fact that intramembranous particles of the erythrocyte membrane are reorganized into a rhomboidal array in the junctional region (24). Since the intramembraneous particles of the erythrocyte membrane are formed by band 3 (27), the rearrangement may be due to binding of the merozoite to erythrocyte band 3 .

Band 3 is a major transmembrane glycoprotein of the erythrocyte membrane and functions in anion transport (26). It is interesting that the glycophorins, the other major group of glycoproteins of the erythrocyte membrane, are probably involved in invasion by $P$. falciparum (28-31). The glycophorins are not involved in invasion by $P$. knowlesi; trypsin treatment of erythrocytes that cleaves glycophorin $A$ and $\operatorname{En}\left(a^{-}\right)$ erythrocytes that lack glycophorin $A$ are invaded normally by $P$. knowlesi (28). The two malarias studied to date use the most common proteins on the erythrocyte surface, invade erythrocytes of all ages and reach high parasitemias. Whether malarias that are 
restricted to reticulocytes, such as Plasmodium vivax, utilize other erythrocyte surface determinants for recognition that disappear as the erythrocyte matures is yet to be determined.

\section{ACKNOWLEDGMENTS}

We thank Dr. S. Trost and Dr. M. Waxdal for the column purification of Fab fragments, Dr. R. Howard for advice on erythrocyte labeling, and Dr. I. Green for suggestions on the manuscript.

\section{REFERENCES}

1. Dvorak, J. A., L. H. Miller, W. C. Whitehouse, and T. Shiroishi. 1975. Invasion of erythrocytes by malaria merozoites. Science (Wash. DC). 187:748-750.

2. Aikawa, M., L. H. Miller, J. Johnson, and J. Rabbege. 1978. Erythrocyte entry by malaria parasites. A moving junction between erythrocyte and parasite. J. Cell Biol. 77:72-82.

3. McGhee, R. B. 1953. The infection by Plasmodium lophurae of duck erythrocytes in the chick embryo. $J$. Exp. Med. 97:773-782.

4. Butcher, G. A., G. H. Mitchell, and S. Cohen. 1973. Mechanism of host specificity in malarial infection. $\mathrm{Na}$ ture (Lond.). 244:40-42.

5. Miller, L. H., J. A. Dvorak, T. Shiroishi, and J. R. Durocher. 1973. Influence of erythrocyte membrane com. ponents on malaria merozoite invasion. J. Exp. Med. 138:1597-1607.

6. Miller, L. H., S. J. Mason, J. A. Dvorak, M. H. McGinniss, and I. K. Rothman. 1975. Erythrocyte receptors for (Plasmodium knowlesi) malaria: Duffy blood group determinants. Science (Wash. DC). 189:561-563.

7. Miller, L. H., M. Aikawa, J. G. Johnson, and T. Shiroishi. 1979. Interaction between cytochalasin B-treated malarial parasites and erythrocytes. Attachment and junction formation. J. Exp. Med. 149:172-184.

8. Chin, W., P. G. Contacos, G. R. Coatney, and H. R. Kimball. 1965. A naturally acquired quotidian-type malaria in man transferable to monkey. Science (Wash. $D C)$. 149:865.

9. Köhler, G., and C. Milstein. 1975. Continuous cultures of fused cells secreting antibody of defined specificity. Nature (Lond.). 256:495-497.

10. Galfre, G., S. C. Howe, C. Milstein, G. W. Butcher, and J. C. Howard. 1977. Antibodies to major histochompatibility antigens produced by hybrid cell lines. Nature (Lond.). 266:550-552.

11. Ey, P. L., S. J. Prowse, and C. R. Jenkin. 1978. Isolation of pure $\operatorname{IgG}_{1}, \operatorname{IgG}_{2_{a}}$, and $\operatorname{IgG}_{2}$ immunoglobulins from mouse serum using protein $\mathrm{A}$-Sepharose. Immunochemistry. 15:429-436.

12. Epstein, N., L. H. Miller, D. C. Kaushal, I. J. Iroka, J. Rener, R. J. Howard, R. Asofsky, M. Aikawa, and R. L. Hess. 1981. Monoclonal antibodies against a specific surface determinant on malarial (Plasmodium knowlesi) merozoites block erythrocyte invasion. J. Immunol. 127:212-217.

13. Porter, R. R. 1959. The hydrolysis of rabbit $\gamma$-globulin and antibodies with crystalline papain. Biochem. $J$. 73:119-126.

14. Morrison, M. 1974. The determination of the exposed proteins on membranes by the use of lactoperoxidase. Methods Enzymol. 32:103-109.
15. Gahmberg, G. G., and L. C. Andersson. 1977. Selective radioactive labeling of cell surface sialoglycoproteins by periodate-tritiated borohydride. J. Biol. Chem. 252:58885894.

16. Cabantchik, Z. I., M. Balshin, W. Breuer, and A. Rothstein. 1975. Pyridoxal phosphate: an anionic probe for protein amino groups exposed on the outer and inner surfaces of intact human red blood cells. J. Biol. Chem. 250:5130-5136.

17. Laemmli, U. K. 1970. Cleavage of structural proteins during the assembly of head of bacteriophage $\mathrm{T}_{4} \cdot \mathrm{Na}$ ture (Lond.). 277:680-685.

18. Bonner, W. M., and R. A. Laskey. 1974. A film detection method for tritium-labelled proteins and nucleic acids in polyacrylamide gel. Eur. J. Biochem. 46:83-88.

19. Schnell, K. F., S. Gerhardt, and A. Schoppe-Fredenburg. 1977. Kinetic characteristics of the sulfate self-exchange in human red blood cells and red blood cell ghosts. $J$. Membr. Biol. 30:319-350.

20. England, B. J., R. B. Gunn, and T. L. Steck. 1980. An immunologic study of band 3 , the anion transport protein of the human red blood cell membrane. Biochim. Biophys. Acta. 623:171-182.

21. Brackenbury, R., J.-P., Thiery, U. Rutishauser, and G. M. Edelman. 1977. Adhesion among neural cells of the chick embryo. I. An immunological assay for molecules involved in cell-cell binding. J. Biol. Chem. 252:6835-6840.

22. Bertolotti, R., U. Rutishauser, and G. M. Edelman. 1980. A cell surface molecule involved in aggregation of embryonic liver cells. Proc. Natl. Acad. Sci. USA. 77:48314835 .

23. Hyafil, F., C. Babinet, and F. Jacob. 1981. Cell-cell interactions in early embryogenesis: a molecular approach to the role of calcium. Cell. 26:447-454.

24. Aikawa, M., L. H. Miller, J. R. Rabbege, and N. Epstein. 1981. Freeze-fracture study on the erythrocyte membrane during malarial parasite invasion. J. Cell Biol. 91:55-62.

25. Miller, L. H., F. M. McAuliffe, and S. J. Mason. 1977. Erythrocyte receptors for malaria parasites. Am. J. Trop. Med. Hyg. 26:204-208.

26. Cabantchik, Z. I., P. A. Knauf, and A. Rothstein. 1978. The anion transport system of the red blood cell. The role of membrane protein evaluated by the use of 'probes.' Biochim. Biophys. Acta. 515:239-302.

27. Pinto da Silva, P., and G. L. Nicolson. 1974. Freeze-etch localization of concanavalin A receptors to the membrane-intercalated particles of human erythrocyte ghost membranes. Biochim. Biophys. Acta. 363:311-319.

28. Miller, L. H., J. D. Haynes, F. M. McAuliffe, T. Shiroishi, J. R. Durocher, and M. McGinniss. 1977. Evidence for differences in erythrocyte surface receptors' for the malarial parasites, Plasmodium falciparum and Plasmodium knowlesi. J. Exp. Med. 146:277-281.

29. Perkins, M. 1981 . Inhibitory effects of erythrocyte membrane proteins on the in vitro invasion of the human malarial parasite (Plasmodium falciparum) into its host cell. J. Cell Biol. 90:563-567.

30. Pasvol, G., J. S. Wainscoat, and D. J. Weatherall. 1982. Erythrocytes deficient in glycophorin resist invasion by the malarial parasite Plasmodium falciparum. Nature (Lond.). 297:64-66.

31. Pasvol, G., M. Jungery, D. J. Weatherall, S. F. Parsons, D. J. Anstee, and M. J. A. Tanner. 1982. Glycophorin as a possible receptor for Plasmodium falciparum. Lancet. II:947-950. 